\title{
PENGEMBANGAN PERALATAN PRAKTIKUM PADA MATAKULIAH FISIKA KEBUMIAN LANJUT
}

\author{
Nur Islami \\ Pendidikan Fisika, Universitas Riau \\ Jl. HR. Soebrantas, KM. 12.5. Pekanbaru, 28293, Indonesia \\ nurislami@lecturer.unri.ac.id
}

\begin{abstract}
ABSTRAK: Salah satu matakuliah di Program Studi Pendidikan Fisika yang memerlukan pengamatan langsung dilapangan adalah Fisika Kebumian Lanjut. Pada matakuliah ini terdapat salah satu pokok bahasan Air Tanah. Penelitian ini bertujuan untuk mengembangkan sebuah peralatan reistivitas geolistrik yang dapat digunakan pada praktikum lapangan oleh mahasiswa Program Studi Pendidikan Fisika Universitas Riau. Metode yang digunakan adalah metode Research dan Pengembangan. Keperluan alat dianalisa sehingga memunculkan ide untuk pembuatan alat. Alat didesign sedemikian rupa dengan mempertimbangkan tingkat kelesamatan, kemudahan penggunaan sampai pada akurasi. Hasil penelitian menunjukkan alat yang dikembangkan berhasil dibuat dengan baik. Peralatan di validasi oleh para pakar dan diuji coba dilapangan. Empat orang pakar yaitu dosen Fisika memberikan penilaian dengan rata rata 3.75 dalam skala 4. Dengan demikian alat ini sudah dapat digunakan pada praktikum perkuliahan Fisika Kebumian Lanjut di Program Studi Pendidikan Fisika Universitas Riau.
\end{abstract}

Kata kunci: Fisika Kebumian Lanjut, Geolistrik, Praktikum. 


\title{
DEVELOPMENT OF PRACTICAL EQUIPMENT IN ADVANCE EARTH PHYSICS
}

\begin{abstract}
One of the courses in the Physics Education Study Program that requires direct observation in the field is Advanced Earth Physics. In this course there is one subject that discusses about Groundwater. This study aims to develop a geoelectrical resistivity equipment that can be used in field work by students of the Riau University Physics Education Study Program. The method used was the Research and Development method. The need for tools was analyzed so that ideas for making tools emerge. The tool is designed in such a way as to consider the level of safety, ease of use and antil the acuracy. The results showed that the tools developed were successfully made well. The equipment was validated by experts and field tested. Four experts of Physics lecturers gave an average rating of 3.7on a scale of 4. Thus this tool can already be used in Advanced Earth Physics lectures in the Physics Education Study Program at the University of Riau.
\end{abstract}

Keywords : Advance earth physics, Geoelectric, Practical

\section{PENDAHULUAN}

Proses pendidikan dan pengajaran memerlukan peralatan untuk melakukan observasi dan juga pengamatan langsung dilapangan. Proses observasi dilapangan akan memberikan nilai tersendiri pada peserta didik yang sedang melakukan observasi tersebut (Bambang, 2010; Lin dkk, 2017). Pada Program Studi Pendidikan Fisika Universitas Riau, terdapat satu matakuliah yaitu Fisika Kebumian Lanjut, yang mana pada matakuliah ini mahasiswa dihadapkan pada masalah kebumian. Salah satu pokok bahasan matakuliah ini adalah Air Tanah. Untuk memahami keberadaan air tanah, perlu menggunakan suatu alat salah satunya dinamakan alat resistivitas geolistrik (islami, 2010). Dengan menggunakan alat ini mahasiswa akan bisa langsung mengadakan praktikum dilapangan guna memahami konsep fisika yang diaplikasikan pada kajian air tanah. Dengan demikian mahasiswa program studi pendidikan fisika akan lebih memahami materi ini dengan baik dan secara komprehensif menerapkan ilmu fisika lainnya yang didapat pada semester sebelumnya.

Kualitas investasi serta transformasi dibidang pendidikan Nasional, adalah sesuatu yang perlu diberikan penekanan sehingga bidang pendidikan dapat menjadi bagian yang menggemilangkan (Depdikbud, 2013; Mulyasa, 2008). Dengan demikian suatu upaya untuk mencapai hasil yang berkualitas ini, diperlukan sumber daya pendidikan yang baik, salah satunya adalah pengadaan peralatan praktikum sesuai dengan target pembelajaran yang diinginkan. Dengan menggunakan peralatan praktikum yang memadai, para mahasiswa akan 
mendalami keilmuannya dengan berhadapan langsung pada masalah yang dihadapinya (Jamaluddin, 2015; Nawzad dkk, 2018; Ivanović dkk, 2018).

Pengajaran pokok bahasan airtanah, selama ini hanya menggunakan media animasi yang diperoleh dari internat. Media animasi ini memiliki kekurangan yaitu mahasiswa tidak dapat melakukan pengamatan dan pengambilan data secara langsung. Namun permasalahannya adalah bahwa peralatan resistivitas geolistrik dijual dengan harga yang jukup fantastik, lebih dari 50 juta rupiah sampai bahkan ratusan juta rupiah. Harga ini tergantung dari kekomplitan alat yang ditawarkan. Peratan resistivitas geolistrik ini dapat juga digunakan untuk explorasi kebumian lainnya seperti explorasi kualitas air tanah (Islami dkk, 2018), dan eksploarasi keberadaan gambut (Islami dkk, 2018).

Pada penelitian ini akan dibahas pembuatan peralatan praktikum Fisika Kebumian Lanjut husus nya resistivitas geolistrik dari analisa keperluan sampai pada uji validitas yang diberikan pada validator yang ahli bidang media dan bidang fisika kebumian.

\section{METODE}

Penelitian pengembangan ini tidak melibatkan mahasiswa Pendidikan Fisika Universitas Riau. Penelitian ini dilakukan di Laboratorium Pendidikan Fisika Univeritas Riau mulai dari Januari 2018 hingga April 2018.

Gambar 1 memperlihatkan alur pembuatan alat resistivitas geolistrik. Dimulai dari analisa keperluan sampai pada hasil akhir yang diperoleh. Pertama sekali dilakukan analisis keperluan. Kemudian peralatan didesain dengan baik untuk mememnuhi semua kriteria yang diperlukan. Kemudian peralatan dibuat dan selanjutnya dilakukan uji coba dilapangan sebelum dilakukan validasi oleh para ahli. Setelah uji coba berhasil, dilakukan validasi oleh para ahli untuk mendapat penilaian dari berbagai aspek dari team Pakar. Team pakar adalah Dosen dari Pendidikan Fisika dan Dosen Fisika Universitas Riau.

Proses validasi yang dinilai pada pembuatan peralatan ini adalah dengan maksud memenuhi kriteria indikator pencapaian yang dapat digunakan sebagai peralatan praktikum, yaitu fungsi, kenyamanan, keamanan, estetika, nilai ekonomi, ukuran, dan penggunaan media. Tingkat akurasi mahir adalah 3 dosen yang memiliki kapasitas untuk melakukan penilaian pada geolistrik media pembelajaran. Validasi alat menggunakan kuesioner dengan penilaian dari 1 hingga 4 (skala Likert) sehingga akan didapat hasil validitas peralatan praktikum yang telah dihasilkan. 


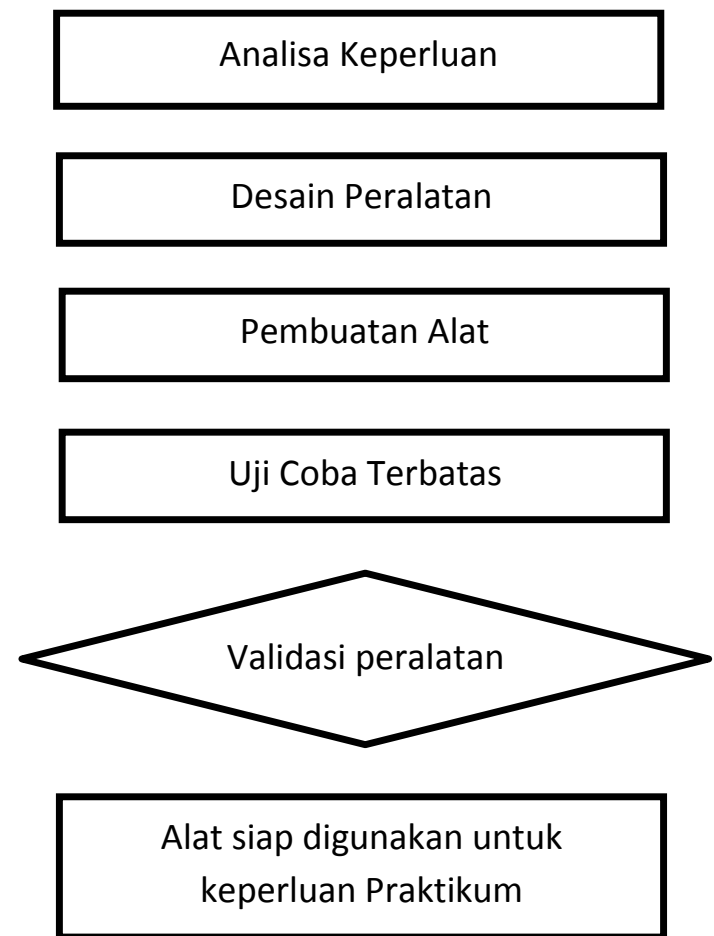

Gambar 1. Proses pembuatan peralatan Praktikum

\section{HASIL DAN PEMBAHASAN}

\section{Analisa Keperluan}

Proses analisa keperluan berdasarkan keperluan praktikum pada salah satu topik yaitu Air Tanah. Pada topik ini terdapat keperluan untuk mengetahui lokasi air tanah pada aquifer dalam tanah sehingga diperlukan sebuah alat yang dapat mendeteksi dan memetakan lokasi keberadaan air tanah. Salah satu alat yang dapat di buat untuk keperluan ini adalah resistivitas geolistrik. Peralatan ini dapat dibuat di laboratorium Pendidikan Fisika Universitas Riau.

\section{Desain Peralatan}

Gambar 1 adalah desian peralatan yang akan di buat. Peralatan terdiri dari sumber arus tegangan DV $12 \mathrm{~V}$. Sumber arus DC ini akan diubah menjadi tegangan AC yang memiliki pilihan penaik tegangan. Dengan demikian dapat digunakan berdasarkan keperluan. Setelah itu diteruskan pada pengubah tegangan $\mathrm{AC}$ ke tegangan DC yang kemudian dilanjutkan pada pengontrol arus. Dari sini akan di baca langsung tegangan dan arus keluaran dari alat. Arus dari peralatan akan di teruskan ke elektroda yang di tancapkan pada permukaan tanah sehingga dapat dialirkan ke dalam lapisan tanah. 


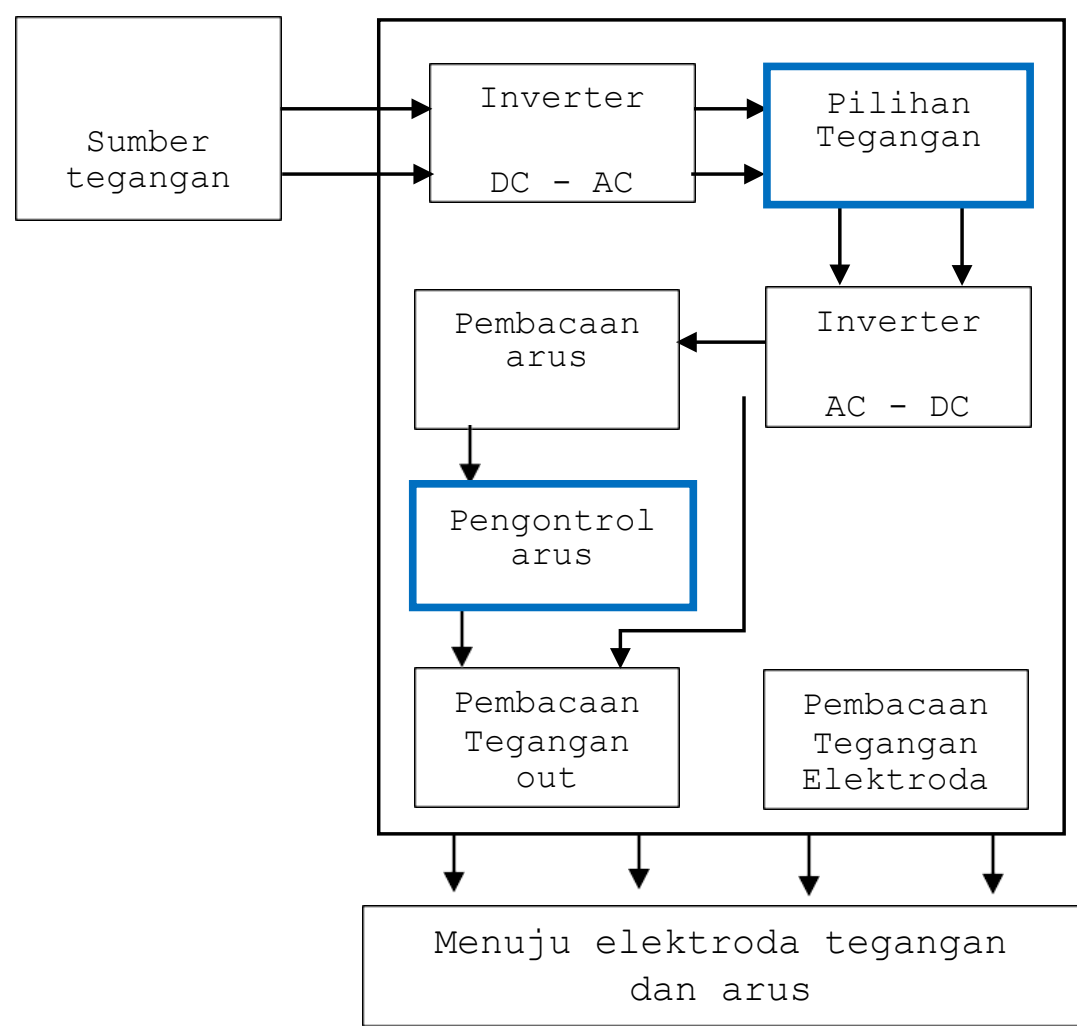

Gambar 1. Skema peralatan yang akan dibuat

\section{Pembuatan Peralatan}

Pembuatan alat dilakukan di laboratorium Pendidikan Fisika Universitas Riau. Gambar 2 adalah alat praktikum yang sudah dihasilkan. Peralatan praktikum Fisika Kebumian Lanjut ini dihasilkan dengan merangkai komponen komponen yang diperlukan dan diuji secara sistematis di laboratorium. Pada gambar 2 terlihat peralatan yang sudah dibuat sebelum dilakukan pengkasingan.

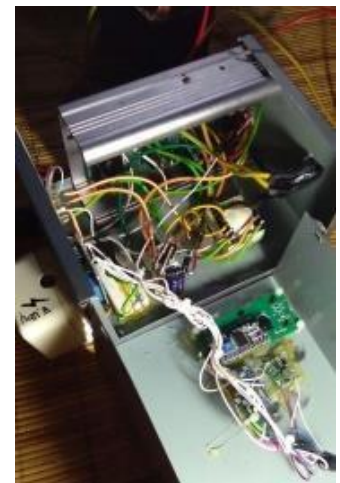

Gambar 2. Peralatan praktikum Fisika Kebumian Lanjut untuk topik Airtanah 


\section{Uji Coba Terbatas}

Proses ujicoba terbatas dilakukan disekitar permandian kolom air panas di Rokan Hulu. Gambar 3 adalah ujicoba peralatan yang sekaligus untuk meng explorasi air tanah yang ada disekitar pemandian air panas. Gambar 4 adalah hasil dari pemodelan data yang telah didapatkan pada proses pengujian terbatas di lapangan.

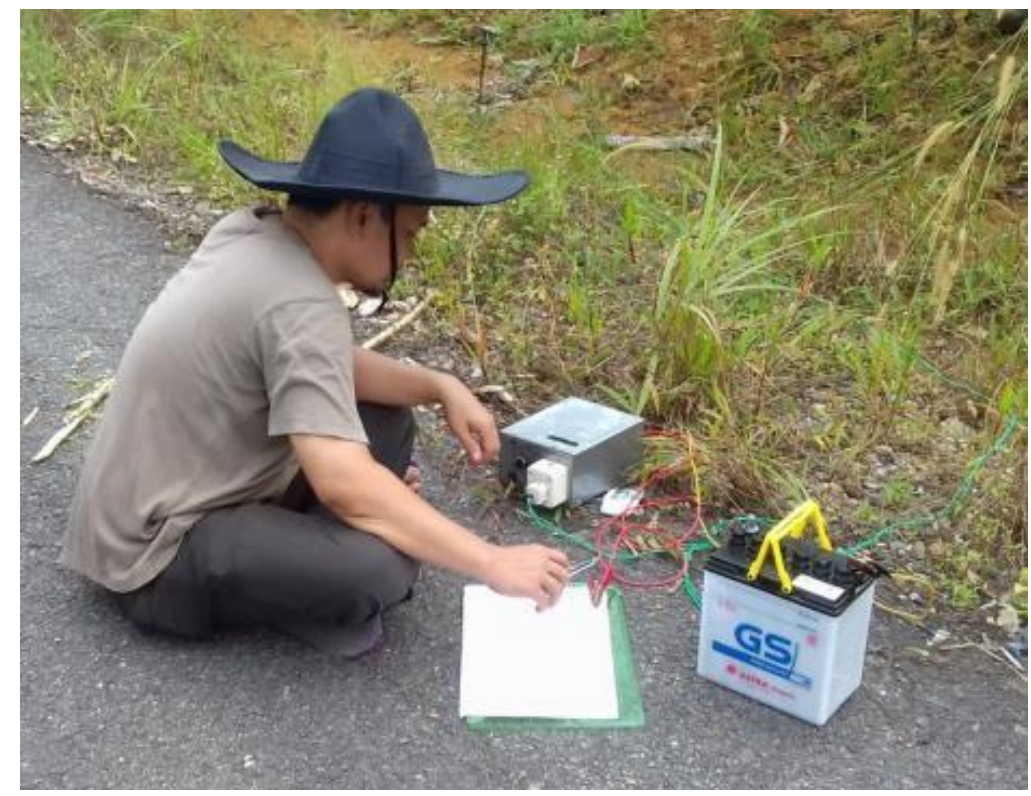

Gambar 3. Pengujian alat secara terbatas di lapangan

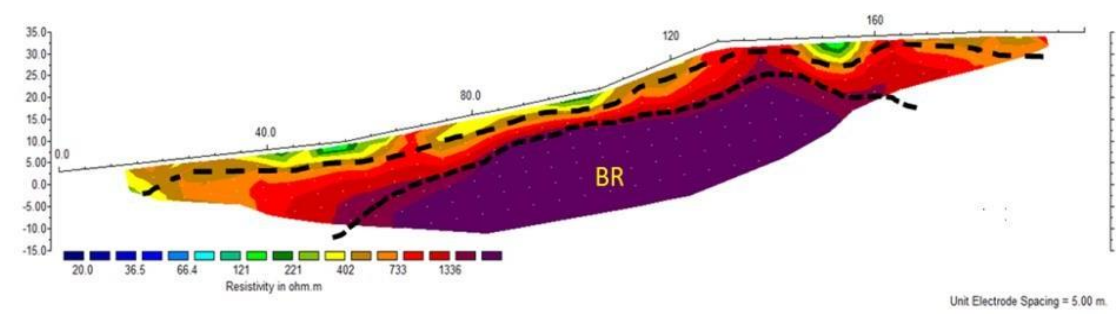

Gambar 4. Salah satu hasil ujicoba terbatas peralatan yang di buat

\section{Validasi Peralatan}

Setelah dilakukan pengujian terbatas pada alat yang dibuat, kemudian dilakukan penilaian oleh para ahli, yaitu ahli media dan ahli fisika kebumian. Empat orang Dosen dari Pendidikan fisika dan dari Fisika FMIPA telah dipilih untuk melakukan validasi ini. Tabel 1 adalah hasil rata rata penilaian oleh para ahli yang dimaksud. 
Tabel 1. Rata rata penilaian dari keempat validator

\begin{tabular}{lcc}
\hline No. Indikator & Rata Rata & Kategori \\
\hline 1. Fungsi & 3.8 & Sangat Baik \\
2. Kemudahan & 3.7 & Sangat Baik \\
3. Keamanan & 3.9 & Sangat Baik \\
4. Keindahan & 3.4 & Sangat Baik \\
5. Keekonomisan & 3.9 & Sangat Baik \\
6. Ukuran & 3.9 & Sangat Baik \\
7. Akurasi penggunaan & 3.8 & Sangat Baik \\
\hline \multicolumn{1}{c}{ Total } & 3.7 & Sangat Baik \\
\hline
\end{tabular}

Pada Tabel.1 terdapat penilaian yang telah dilakukan oleh para ahli yang di evaluasi untuk beberapa elemen yaitu:

\section{a. Berfungsi}

Penilaian ini mengacu pada fungsi yang dihasilkan oleh peralatan yang telah dibuat. Pada aspek ini diperoleh nilai rata-rata dari pakar adalah 3.8. Para pakar memberikan penilaian bahwa peralatan yang dibuat ini dapat berfungsi dengan baik dan memberikan sumbangan pada kemudahan praktikum pada mahasiswa nantinya.

\section{b. Kemudahan}

Untuk kategori kemudahan, peralatan ini memiliki kemudahan dalam proses pemakainnya. Oleh sebab itu para pakar memberikan penilaian rata rata adalah 3.7 dengan kategori sangat baik. Para pakar menyatakan bahwa peralatan ini sangat mudah digunakan.

c. Keamanan

Penilaian terhadap keamanan alat dari segi keselamatan penggunaan dikukan oleh ahli pakar . Nilai rata-rata yang diperoleh dari pakar adalah 3.9 yang dapat dikategorikan sangat tinggi. Ini memberikan makna bahwa peralatan praktikum yang dibuat aman untuk digunakan dalam praktikum nantinya.

d. Estetika (keindahan) 
Indikator estetika adalah penilaian untuk bagian kerapian secara fisik peralatan yang dibuat. Pada poin ini validator yang terdiri dari para pakar memberikan nilai rata rata skor rata-rata adalah 3,4 dengan kategori sangat baik.

e. Nilai ekonomi.

Untuk kategori indikator nilai ekonomi, pada peralatan praktikum yang dibuat ini, para ahli memberikan penilaian rata rata 3.9. Adapun komentar para ahli bahwa sanya peralatan yang sama dijual dengan harga puluhan bahkan ratusan juta rupiah. Sementara yang dibuat ini hanya memakan biaya sebetar 2 juta rupiah saja.

\section{f. Ukuran}

Dari segi ukuran, para ahli memberikan penilaian rata rata 3.9 karena peralatan yang berfungsi sama yang dijual adalah berukuran jauh lebih besar deari peralatan yang dibuat ini. Dengan demikian peralatan praktikum yang dibuat ini sangat nyaman dari segi ukuran.

\section{g. Akurasi Penggunaan.}

Akurasi mengacu pada penggunaan peralatan pada praktikum dan juga akurasi alat yang dihasilkan terhadap kompetensi yang diinginkan dalam praktikum. Para pakar memberikan nilai rata rata yaitu 3.8 karena peralatan memeiliki akurasi yang tinggi dan sasaran yang tepat. Total akhir untuk rata rata semua kategori yaitu 3.7 dengan kategori sangat baik. Dengan demikian peralatan sangat cocok sekali untuk digunakan pada praktikum Fisika Kebumian Lanjut.

\section{KESIMPULAN}

Peralatan untuk keperluan praktikum pada matakuliah Fisika Kebumian Lanjut hususnya topik pokok bahasan airtanah di Program Studi Pendidikan Fisika Universitas riau sudah berhasil di lakukan dengan baik. Keberhasilan pembuatan peralatan ini terlihat dari penilaian para ahli yang memberikan penilaian dengan kategori sangat bagus untuk rata rata ketujuh poin penilaian. Dengan demikian peralatan ini sudah bisa digunakan dalam proses pembelajaran pada topik bahasan Airtanah pada matakuliah Fisikan Kebumian Lanjut. 


\section{DAFTAR PUSTAKA}

Bambang Sumintono. (2010). Guruan Sains Dengan Praktikum Laboratorium : Perspektif Dari Guru-Guru Sains SMPN Di Kota Cimahi. Jurnal Pendidikan MIPA 15(2) : 120127. Universiti Teknologi Malaysia. Malaysia.

Islami, N. (2018). Groundwater Exploration in the Bedrock Area using Geoelectrical Resistivity Survey, IOP Conference Series: Earth and Environmental Science 186 (3), 012016.

Depdikbud. 2013. Standar Proses Pendidikan Dasar dan Menengah. Jakarta. Kemendiknas Jamaluddin, Amiruddin Kade, dan Nurjanah. (2015). Analisis Pelaksanaan Praktikum Menggunakan KIT IPA Fisika di SMP Se Kecamatan Sojol Kabupaten Donggala. ejournal Pendidikan fisika Tadulako 3(1) : 6-13.

Islami, N., Taib, S.H., Yusoff, I., Ghani, A.A, (2018). Integrated geoelectrical resistivity and hydrogeochemical methods for delineating and mapping heavy metal zone in aquifer system. Environmental earth sciences 77 (10), 383.

Islami, N., Irianti, M., Nor, M. (2018). Geophysical survey for groundwater potential investigation in peat land area, Riau, Indonesia. IOP Conference Series: Earth and Environmental Science 144 (1), 012001.

Lin, M.H., Chen, H.C., and Liu, K.S, 2017, A Study of the Effects of Digital Learning on Learning Motivation and Learning Outcome. EURASIA Journal of Mathematics Science and Technology Education, 13 (7), 3553-3564.

Nawzad, L., Rahim, D., Wakil, K., 2018, The Effectiveness of Technology for Improving the Teaching of Natural Science Subjects. Indonesian Journal of Curriculum and Educational Technology Studies (IJCETS), 6(1), 15-21.

Ivanović, M., Milićević, A.K., Aleksić, V., Bratić, B., Mandić, M., 2018, Experiences and Perspectives of Technology-enhanced Learning and Teaching in Higher Education Serbian Case. Procedia Computer Science, 126 (2018), 1351-1359.

Mulyasa. 2008. Menjadi Guru Profesional Menciptakan Pembelajaran Kreatif dan Menyenangkan. Remaja Rosda Karya. Bandung. 